\title{
Carbon C 11 Choline
}

National Cancer Institute

\section{Source}

National Cancer Institute. Carbon C 11 Choline. NCI Thesaurus. Code C78485.

A radiotracer consisting of choline labeled with the positron-emitting isotope carbon C 11 with potential imaging use. Upon administration, C-11 choline incorporates into tumor cells through an active, carrier-mediated transport mechanism for choline and then is phosphorylated intracellularly by choline kinase, an enzyme frequently upregulated in human tumors, yielding phosphoryl C-11 choline. In turn, phosphoryl C-11 choline is integrated into phospholipids in the cell membrane as part of phosphatidylcholine. As the proliferation of cancer cells is much higher than normal cells, tumor cells exhibit an increased rate of C-11 choline uptake and incorporation, allowing tumor imaging with positron emission tomography (PET). 